Research Article

\title{
Hydrothermal Synthesis, Structural Characterization, and Interaction Mechanism with DNA of Copper(II) Complex Containing 2,2' -Bipyridine
}

\author{
Ting Liu $(\mathbb{D}$, Yi-An Wang, Qing Zang, and Guo-Qing Zhong $\mathbb{1}$ \\ School of Material Science and Engineering, Southwest University of Science and Technology, Mianyang 621010, China \\ Correspondence should be addressed to Guo-Qing Zhong; zgq316@163.com
}

Received 28 February 2018; Accepted 8 April 2018; Published 22 May 2018

Academic Editor: Concepción López

Copyright ( $\odot 2018$ Ting Liu et al. This is an open access article distributed under the Creative Commons Attribution License, which permits unrestricted use, distribution, and reproduction in any medium, provided the original work is properly cited.

A Cu(II) complex $\left[\mathrm{Cu} \text { (bipy) }\left(\mathrm{H}_{2} \mathrm{O}\right)_{2}\left(\mathrm{SO}_{4}\right)\right]_{n}$ (bipy = 2,2' -bipyridine) was synthesized by hydrothermal method and characterized structurally by elemental analyses, single crystal X-ray diffraction, infrared spectra, and thermogravimetry and differential scanning calorimetry. The $\mathrm{Cu}(\mathrm{II})$ was hexacoordinated by two $\mathrm{N}$ atoms from bipy, two $\mathrm{O}$ atoms from different sulfate radical anions, and two $\mathrm{O}$ atoms from two water molecules, forming a slightly distorted octahedral geometry, and bridged by sulfato groups into polymeric chains. Under the condition of physiological $\mathrm{pH}$, the interaction mechanism between the complex and hsDNA was explored with acridine orange as a fluorescence probe by spectroscopic methods. The binding modes between the complex and hsDNA were the electrostatic and embedded modes.

\section{Introduction}

Design and synthesis of organometallic complexes have become an active research area because of their novel topologies, fascinating functionalities, special properties, and potential applications, such as biomedical utilization, multifunctional materials, molecular adsorption, gas storage, catalysis, magnetism, and so on [1-6]. Chemists have synthesized many organic-inorganic hybrid materials with nitrogen heterocyclic compounds as organic building blocks [7-10]. Trace element copper plays an important role in endogenous oxidative DNA damage associated with aging and cancer $[11,12]$. $\mathrm{Cu}(\mathrm{II})$ complexes have many bioactivities such as antitumor [13, 14], antimicrobial [15-17], and oxidation of ascorbic acid in the presence of oxygen [18]. In addition, $\mathrm{Cu}$ (II) complexes can bind to DNA through noncovalent and covalent interactions [19]. Many researchers found that $\mathrm{Cu}(\mathrm{II})$ complexes had potential in the treatment of cancers and other diseases [20]. 2,2'-Bipyridine is a potential antitumor agent and often acts as ancillary ligand to strengthen the binding ability of a complex through enhancing the molecule planarity [21]. The complexes of $2,2^{\prime}$-bipyridine and its derivatives have been reported by a number of authors $[22,23]$. The method of hydrothermal synthesis has been used to produce various solids, such as oxide ceramics, microporous crystals, metal complexes, nanomaterials, and so forth [24-29]. In particular, the molecular structures obtained by this method are unexpected compared with those obtained by the common solution method [30].

The modes of noncovalent interaction for metal complexes with DNA include intercalation, electrostatic effect, groove binding, and so on, and the effectiveness mainly depends on the binding modes and affinities between complexes and DNA [31-34]. There is continuing interest in some metal complexes that interact with DNA [35]. Furthermore, the studies of interaction of metal coordination polymers with DNA have been of great interest $[36,37]$. However, examples of such metal coordination polymers are still few. Therefore, it is of great significance to explore the binding modes of DNA with metal coordination polymers containing rigid ligands.

We herein report the X-ray single crystal structure, Fourier transform infrared spectra (FTIR), and thermogravimetry and 
differential scanning calorimetry (TG-DSC) of the $\mathrm{Cu}(\mathrm{II})$ complex containing $2,2^{\prime}$-bipyridine, which is synthesized by hydrothermal method, and explore its bioactivities with herring sperm DNA (hsDNA) using acridine orange (AO) as a fluorescence probe by spectral methods.

\section{Materials and Methods}

2.1. Materials. All chemicals were of analytical reagents and used as received without further purification. 2,2'-Bipyridine and $\mathrm{AO}$ were purchased from Alfa Aesar, and copper sulfate pentahydrate and other reagents were purchased from Merck. The hsDNA was purchased from Sigma Biological Co., its purity was monitored by the ratio of absorbance at $260-280 \mathrm{~nm}$, and the ratio of $1.8-1.9$ indicated that the hsDNA was free from protein. The hsDNA was dissolved in double-distilled water with $50 \mathrm{mmol} \cdot \mathrm{L}^{-1}$ sodium chloride and dialyzed at $4^{\circ} \mathrm{C}$ for $48 \mathrm{~h}$ [38]. The hsDNA concentration was measured by UV-Vis at $260 \mathrm{~nm}$. Tris-HCl buffer solution ( $\mathrm{pH} 7.40$ ) was prepared by using triple-distilled water.

2.2. Physical Measurements. The $\mathrm{C}, \mathrm{H}$, and $\mathrm{N}$ in the complex were analyzed with a Vario EL CUBE elemental analyzer, and the copper was determined by EDTA titration. FTIR spectra were obtained with $\mathrm{KBr}$ pellets on a Perkin-Elmer Spectrum One-Spectrometer in the range $4000-400 \mathrm{~cm}^{-1}$. The thermal analysis was performed by a SDT Q600 thermogravimetric analyzer from 30 to $800^{\circ} \mathrm{C}$ at a heating rate of $10^{\circ} \mathrm{C} \cdot \mathrm{min}^{-1}$ under air flow of $100 \mathrm{~mL} \cdot \mathrm{min}^{-1}$. UV-Vis spectra in Tris- $\mathrm{HCl}$ buffer solution $(\mathrm{pH} 7.40)$ were measured with a Unico spectrophotometer (UV-2102) in the range $200-600 \mathrm{~nm}$. Fluorescence spectra were recorded on a PE LS-55 spectrofluorophotometer. Viscosities were measured with an Ubbelohde capillary viscometer having diameters of $0.40-0.50 \mathrm{~nm}$ and $0.50-0.60 \mathrm{~nm}$, respectively. The viscometers were selected on the basis of the flow time of the complex, and the flow time was at least $120 \mathrm{~s}$.

2.3. Synthesis of the Title Complex. 2,2'-Bipyridine $(0.2 \mathrm{mmol}$, $31.7 \mathrm{mg})$ and $\mathrm{NaOH}(0.2 \mathrm{mmol}, 8.0 \mathrm{mg})$ were dissolved in a minimum amount of distilled water. Copper sulfate $(0.2 \mathrm{mmol}, 51.3 \mathrm{mg})$ was added to the above solution, and the volume of the mixed solution was increased to $18 \mathrm{~mL}$ with distilled water. The mixture was transferred to a $30 \mathrm{~mL}$ Teflon-lined stainless steel reactor and heated to $140^{\circ} \mathrm{C}$ for $72 \mathrm{~h}$, and then, it was cooled at a rate of $10^{\circ} \mathrm{C} \cdot \mathrm{h}^{-1}$ to room temperature. Blue stick single crystals suitable for X-ray diffraction analysis were obtained. The crystals were washed by a small amount of distilled water and anhydrous ethanol and dried naturally (yield 84\%). Anal. Calc. (\%) for $\mathrm{CuC}_{10} \mathrm{H}_{12} \mathrm{~N}_{2} \mathrm{O}_{6} \mathrm{~S}$ : C, 34.14; H, 3.44; N, 7.96; Cu, 18.06 . Found (\%): C, 34.12; H, 3.30; N, 7.77; Cu 18.14.

2.4. X-Ray Crystallography. A blue crystal with dimensions $0.374 \mathrm{~mm} \times 0.199 \mathrm{~mm} \times 0.117 \mathrm{~mm}$ was installed on a Bruker Apex II CCD diffractometer with graphite monochromated Mo $K_{\alpha}$ radiation $(\lambda=0.71073 \AA)$. Diffraction data were collected at $296(2) \mathrm{K}$ in the $\theta$ range $3.273-27.639^{\circ}$. The programs of the SHELXL-97 and SHELXTL-97 were used for the structure determination and refinement $[39,40]$. The structure was solved by direct methods, and all nonhydrogen atoms were obtained from the difference Fourier map and subjected to anisotropic refinement by full-matrix least squares on $F^{2}$. Crystallographic data have been deposited with the Cambridge Crystallographic Data Centre, CCDC, UK. Copies of the data can be obtained free of charge on quoting the depository CCDC-1028718 for the title complex (deposit@ccdc.cam.ac.uk, http://www.ccdc.cam.ac.uk).

2.5. Procedures of Biological Activity. The experimental methods of biological activity were mainly referred to $[38,41]$. The specimens for absorption and fluorescence were obtained through diluting the stock solutions of the title complex (abbreviated as Cu-bipy) and hsDNA with Tris$\mathrm{HCl}$ buffer solution to the required concentrations. Under the condition of the fixed Cu-bipy concentration and changing only the hsDNA concentration, the spectra of UVVis and fluorescence were tested with the quartz cuvettes of $1 \mathrm{~cm}$. The excitation wavelength of the fluorescence measurement was $411.7 \mathrm{~nm}$.

The samples of viscosity measurement were filled into the cleaned and dried viscometers. A thermostat was used to keep the temperature constant with the deviations within $\pm 0.01^{\circ} \mathrm{C}$. Double-distilled water was used in the calibration experiments, and the viscosity of pure water was derived from Lange's Handbook of Chemistry [42]. The time was recorded on a digital stopwatch with the deviations within $\pm 0.01 \mathrm{~s}$, and the average deviation of the three experimental results was within $\pm 0.2 \mathrm{~s}$. The hsDNA of $1.0 \times 10^{-5} \mathrm{~mol} \cdot \mathrm{L}^{-1}$ was mixed with different concentrations of Cu-bipy. The flow time was recorded at $20 \pm 0.1^{\circ} \mathrm{C}$ after the reaction mixture was placed in the darkness for $0.5 \mathrm{~h}$. The relative viscosities of hsDNA were measured with molar ratio $(r=c(\mathrm{Cu}$-bipy $) / c(\mathrm{hsDNA}))$ from 0.0 to 4.0 at atmospheric pressure and $15^{\circ} \mathrm{C}$ ambient temperature.

\section{Results and Discussion}

3.1. Crystal Structure Analysis. The molecular structure diagram of the complex is shown in Figure 1. The crystallographic data and structure refinement parameters are given in Table 1, and the selected bond distances and angles are shown in Table 2.

The unit of the complex is composed of one $\mathrm{Cu}(\mathrm{II})$, one $2,2^{\prime}$-bipyridine, two water molecules, and one sulfate radical anion. The $\mathrm{Cu}(\mathrm{II})$ is hexacoordinated by two $\mathrm{O}$ atoms from the coordinated water molecules and two pyridyl $\mathrm{N}$ atoms from bipy which are located at equatorial sites and two $\mathrm{O}$ atoms from different bidentate bridging sulfato groups which are located at axial positions. The coordination configuration is a slightly distorted octahedron, and the $\mathrm{Cu}$ (II) is bridged by sulfato groups into polymeric chains. The distances of $\mathrm{Cu}-\mathrm{O}$ with the aqua ligands and the sulfato group are 1.9728 and $2.455 \AA$, respectively, and the distances of Cu-N are $1.9947 \AA$. Because of Jahn-Teller effect of Cu(II) 


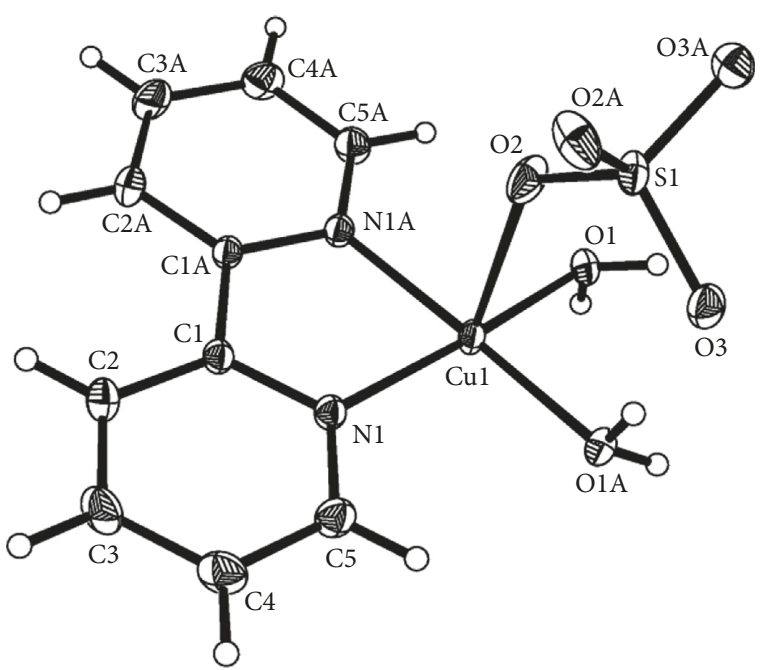

Figure 1: Molecular structure of the title complex.

TABLE 1: Crystal data and structure refinement parameters for the title complex.

\begin{tabular}{ll}
\hline Empirical formula & $\mathrm{CuC}_{10} \mathrm{H}_{12} \mathrm{O}_{6} \mathrm{~N}_{2} \mathrm{~S}$ \\
Formula weight $\left(\mathrm{g} \cdot \mathrm{mol}^{-1}\right)$ & 351.82 \\
Temperature $(\mathrm{K})$ & $296(2)$ \\
Wavelength $(\AA)$ & 0.71073 \\
Crystal system & Monoclinic \\
Space group & $C 2 / c$ \\
$a(\AA)$ & $15.1279(7)$ \\
$b(\AA)$ & $12.4488(6)$ \\
$c(\AA)$ & $6.9987(3)$ \\
$\beta\left({ }^{\circ}\right)$ & $105.9576(13)$ \\
$V\left(\AA^{3}\right)$ & $1267.23(10)$ \\
$Z$ & 4 \\
Calculated density $\left(\mathrm{g} \cdot \mathrm{cm}^{-3}\right)$ & 1.844 \\
Absorption coefficient $\left(\mathrm{mm}^{-1}\right)$ & 1.916 \\
$F(000)$ & 716 \\
Crystal size (mm $\left.{ }^{3}\right)$ & $0.374 \times 0.199 \times 0.117$ \\
$\theta$ range for data collection $\left(^{\circ}\right)$ & $3.273-27.639$ \\
Index ranges & $-19 \leq h \leq 19,-16 \leq k \leq 16$, \\
Reflections collected/unique & $-9 \leq l \leq 8$ \\
Data/restraints/parameters & 9535 \\
Goodness of fit on $F^{2}$ & $1473 / 3 / 97$ \\
Final $R$ indices $(I>2 \sigma(I))$ & 0.974 \\
$R$ indices (all data) & $R_{1}=0.0226, w R_{2}=0.0579$ \\
Largest differential & $R_{1}=0.0238, w R_{2}=0.0589$ \\
peak and hole $\left(\mathrm{e} \cdot \AA^{-3}\right)$ & 0.356 and -0.442 \\
\hline
\end{tabular}

with $d^{9}$ electron configuration, the axial distances of $\mathrm{Cu}$ (1) $-\mathrm{O}(2)$ and $\mathrm{Cu}(1)-\mathrm{O}(2)^{\# 1}$ are stretched. As shown in Figure 2, the generated chains extend along (001) plane direction, and the crossing of the chelate bipy forms the polymeric chains formulated as $\left[\mathrm{Cu}(\text { bipy })\left(\mathrm{H}_{2} \mathrm{O}\right)_{2}\left(\mathrm{SO}_{4}\right)\right]_{n}$. In Figure 3 , the molecular structure shows the existence of face-to-face $\pi-\pi$ stacking weak interaction. The interplanar distances of 3.495-3.627 $\AA$ between two adjacent mirror planes of bipy are normal for weak $\pi-\pi$ interaction. The hydrogen bond lengths and bond angles are given in Table 3, and the molecules of the complex are linked together by intermolecular hydrogen bonds. It is obvious that the
TABLE 2: Selected bond lengths $(\AA)$ and angles $\left({ }^{\circ}\right)$ for the title complex.

\begin{tabular}{ll}
\hline $\mathrm{Cu}(1)-\mathrm{O}(1)$ & $1.9728(11)$ \\
$\mathrm{Cu}(1)-\mathrm{O}(1)^{\# 1}$ & $1.9728(11)$ \\
$\mathrm{Cu}(1)-\mathrm{N}(1)$ & $1.9947(12)$ \\
$\mathrm{Cu}(1)-\mathrm{N}(1)^{\# 1}$ & $1.9948(13)$ \\
$\mathrm{Cu}(1)-\mathrm{O}(2)$ & 2.455 \\
$\mathrm{Cu}(1)-\mathrm{O}(2)^{\# 1}$ & 2.455 \\
$\mathrm{O}(1)^{\# 1}-\mathrm{Cu}(1)-\mathrm{O}(1)$ & $93.07(7)$ \\
$\mathrm{O}(1)^{\# 1}-\mathrm{Cu}(1)-\mathrm{N}(1)$ & $93.11(5)$ \\
$\mathrm{O}(1)-\mathrm{Cu}(1)-\mathrm{N}(1)$ & $172.31(5)$ \\
$\mathrm{O}(1)^{\# 1}-\mathrm{Cu}(1)-\mathrm{N}(1)^{\# 1}$ & $172.31(5)$ \\
$\mathrm{O}(1)-\mathrm{Cu}(1)-\mathrm{N}(1)^{\# 1}$ & $93.11(5)$ \\
$\mathrm{N}(1)-\mathrm{Cu}(1)-\mathrm{N}(1)^{\# 1}$ & $81.12(7)$ \\
$\mathrm{O}(2)-\mathrm{Cu}(1)-\mathrm{O}(1)$ & 85.52 \\
$\mathrm{O}(2)-\mathrm{Cu}(1)-\mathrm{O}(1)^{\# 1}$ & 92.25 \\
$\mathrm{O}(2)-\mathrm{Cu}(1)-\mathrm{N}(1)$ & 89.66 \\
$\mathrm{O}(2)-\mathrm{Cu}(1)-\mathrm{N}(1)^{\# 1}$ & 92.79 \\
$\mathrm{O}(2)-\mathrm{Cu}(1)-\mathrm{O}(2)^{\# 1}$ & 176.77 \\
$\mathrm{O}(2)^{\# 1}-\mathrm{Cu}(1)-\mathrm{O}(1)$ & 92.25 \\
$\mathrm{O}(2)^{\# 1}-\mathrm{Cu}(1)-\mathrm{N}(1)$ & 92.97 \\
$\mathrm{O}(2)^{\# 1}-\mathrm{Cu}(1)-\mathrm{N}(1)^{\# 1}$ & 89.66 \\
$\mathrm{O}(2)^{\# 1}-\mathrm{Cu}(1)-\mathrm{O}(1)^{\# 1}$ & 85.52 \\
\hline
\end{tabular}

Symmetry transformations used to generate equivalent atoms: ${ }^{\# 1-x+2, y}$, $-z+1 / 2 ;{ }^{\# 2}-x+2, y,-z+3 / 2$.

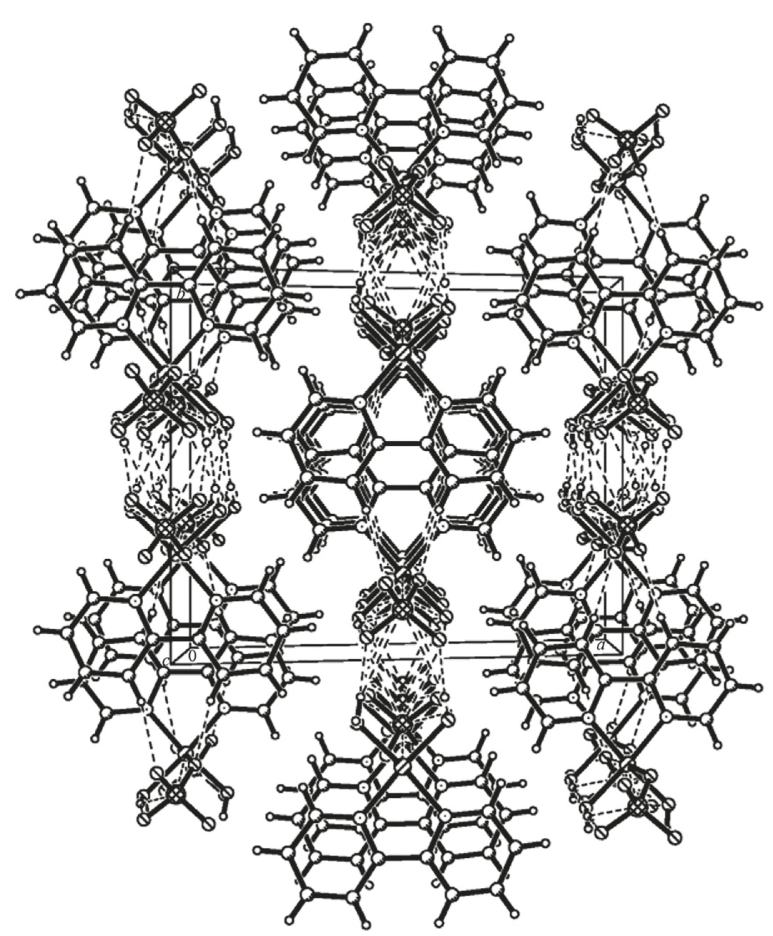

FIGURE 2: Crystal packing diagram of the title complex.

formation of the interchain hydrogen bonds is related to the layers parallel to the (100) plane. A weak hydrogen bond with $d(\mathrm{C} \cdots \mathrm{O})=3.282 \AA$ is formed between the outer $\mathrm{C}-\mathrm{H}$ bonds of one chain and the coordinated sulfato $\mathrm{O}$ atoms of the adjacent chain, and the chains are stabilized by interchain $\pi-\pi$ interaction and interchain $\mathrm{C}-\mathrm{H}$. . O hydrogen bonds [23]. Each water molecule in the complex nearly forms a linear intrachain and interchain hydrogen bonds with the uncoordinated sulfato $\mathrm{O}$ atoms. 


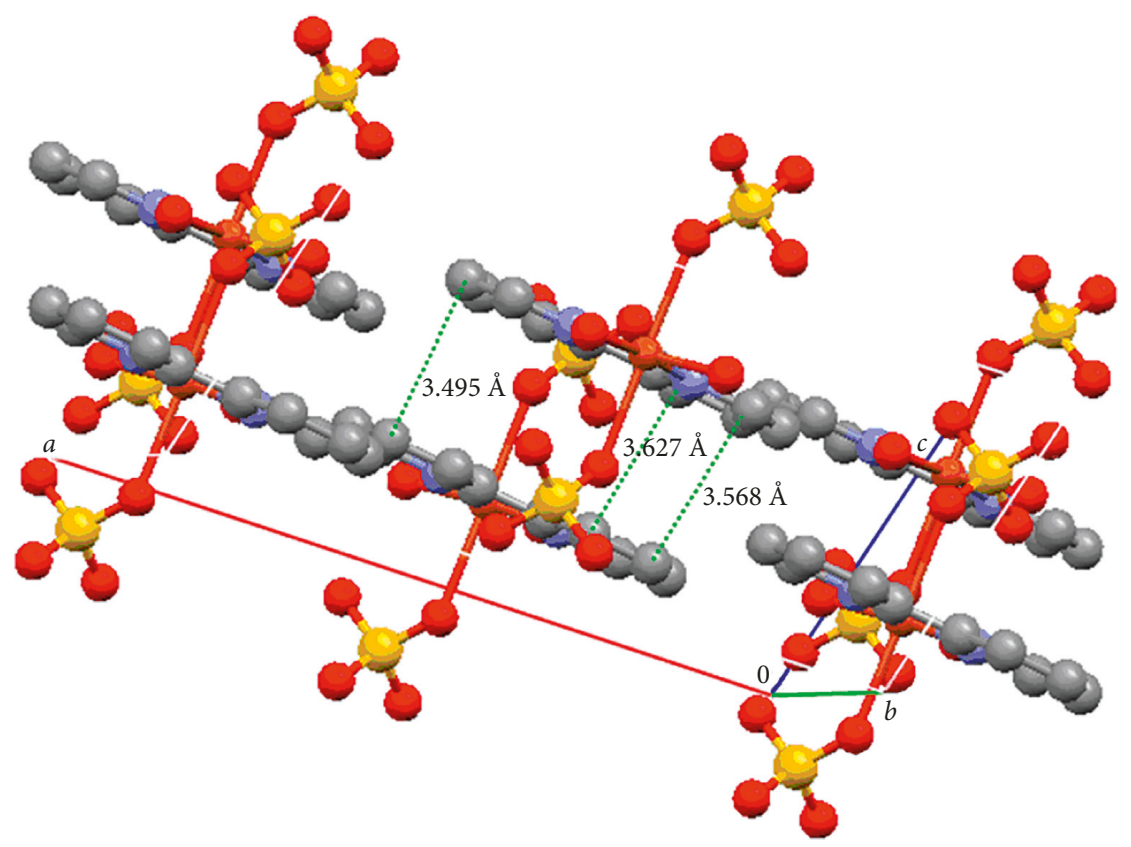

Figure 3: Weak $\pi-\pi$ stacking interactions of the title complex.

TABLe 3: Hydrogen bond lengths $(\AA)$ and bond angles $\left({ }^{\circ}\right)$ for the title complex.

\begin{tabular}{lcccc}
\hline $\mathrm{D}-\mathrm{H} \cdots \mathrm{A}$ & $d(\mathrm{D}-\mathrm{H})$ & $d(\mathrm{H} \cdots \mathrm{A})$ & $d(\mathrm{D} \cdots \mathrm{A})$ & $\angle \mathrm{DHA}$ \\
\hline $\mathrm{O}(1)-\mathrm{H}(1 \mathrm{~W}) \cdots \mathrm{O}(3)^{\# 3}$ & $0.852(9)$ & $1.843(11)$ & $2.6763(16)$ & $165.4(19)$ \\
$\mathrm{O}(1)-\mathrm{H}(1 \mathrm{~W}) \cdots \mathrm{S}(1)^{\# 3}$ & $0.852(9)$ & $2.926(16)$ & $3.6599(12)$ & $145.4(18)$ \\
$\mathrm{C}(5)-\mathrm{H}(5) \cdots \mathrm{O}(1)^{\# 1}$ & 0.93 & 2.50 & $3.026(2)$ & 115.9 \\
$\mathrm{C}(2)-\mathrm{H}(2) \cdots \mathrm{O}(2)^{\# 4}$ & 0.93 & 2.43 & $3.282(2)$ & 152.1 \\
$\mathrm{O}(1)-\mathrm{H}(1) \cdots \mathrm{O}(3)^{\# 1}$ & 0.82 & 1.81 & $2.6198(16)$ & 169.5 \\
$\mathrm{O}(1)-\mathrm{H}(1) \cdots \mathrm{S}(1)^{\# 5}$ & 0.82 & 2.74 & $3.4143(11)$ & 140.8
\end{tabular}

Symmetry transformations used to generate equivalent atoms: ${ }^{\# 1}-x+2, y$, $-z+1 / 2 ;^{\# 2}-x+2, y,-z+3 / 2 ;^{\# 3}-x+2,-y+1,-z+1 ;{ }^{\# 4}-x+2,-y+2,-z+1 ;$ ${ }^{\# 5} x, y, z-1$.

3.2. FTIR Spectroscopy. The FTIR spectrum of the complex is shown in Figure 4. Few number of the absorption bands in the FTIR spectrum means that the symmetry of the complex is very good. A wide intense absorption band around $3428 \mathrm{~cm}^{-1}$ is due to stretching vibration of hydroxyl $[43,44]$. This indicates that there are the coordinated water or lattice water molecules in the complex. The band corresponding to the stretching vibration of the cumulative double bond $(\mathrm{C}=\mathrm{C}-\mathrm{C}=\mathrm{C})$ of pyridine ring is situated at $2328 \mathrm{~cm}^{-1}$. The absorption peaks at 1651 and $1444 \mathrm{~cm}^{-1}$ are assigned to the stretching vibrations of the $\mathrm{C}=\mathrm{N}$ and $\mathrm{C}=\mathrm{C}$ bonds, respectively [45].

As a free anion, sulfate has tetrahedral symmetry, whereas, if sulfate forms a bidentate binuclear (bridging) complex, the symmetry is lowered and the band splits into two bands [46]. As shown in Figure 4, the FTIR spectrum of the complex makes out peaks at 1169 and $1082 \mathrm{~cm}^{-1}$. The absorption peaks around 928 and $775 \mathrm{~cm}^{-1}$ are assigned to the rocking and wagging vibrations of the hydroxyl, which indicate the existence of the coordinated water molecules in the complex [47]. As a result of the formation of the $\mathrm{Cu}-\mathrm{N}$

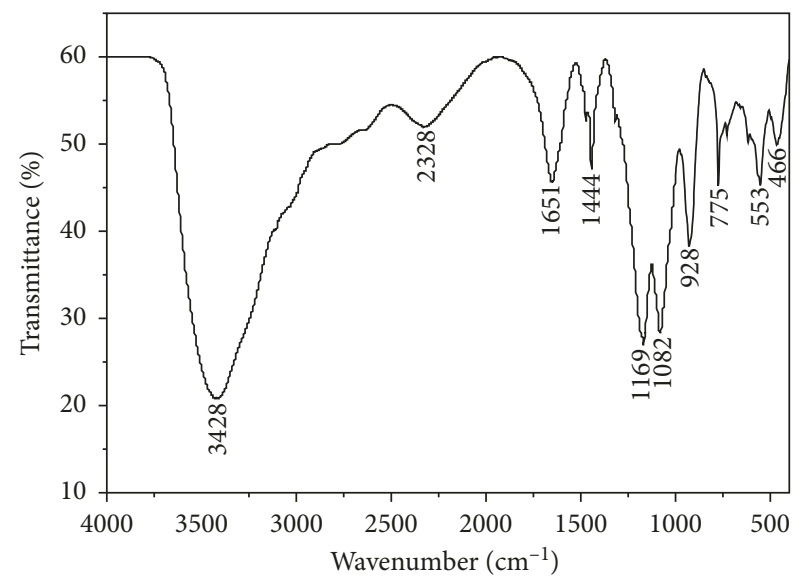

FIGURE 4: FTIR spectrum of the title complex.

bond, the corresponding $\mathrm{C}-\mathrm{N}$ bond becomes so weak that disappeared in the FTIR spectrum [48]. The absorption peaks at 553 and $466 \mathrm{~cm}^{-1}$ are assigned to the $\mathrm{Cu}-\mathrm{N}$ bond and $\mathrm{Cu}-\mathrm{O}$ bond, respectively [49], which agrees with the $\mathrm{X}$-ray crystal structure of the complex.

3.3. Thermal Analysis. The TG-DSC curves of the title complex are shown in Figure 5, and there are one endothermic peak and two exothermic peaks in the DSC curve. The endothermic peak at $169^{\circ} \mathrm{C}$ is accompanied by obvious mass loss, and the sample loses two $\mathrm{H}_{2} \mathrm{O}$ molecules. The experimental mass loss (10.31\%) is close to the calculated one $(10.24 \%)$. Due to the high temperature of water loss, the molecules should be the coordinated water. After the water molecules are lost, the complex becomes $\left[\mathrm{Cu}\left(\mathrm{C}_{10} \mathrm{H}_{8} \mathrm{~N}_{2}\right)\right.$ $\left.\left(\mathrm{SO}_{4}\right)\right]$. The sequential exothermic peaks at 393 and $423^{\circ} \mathrm{C}$ in 


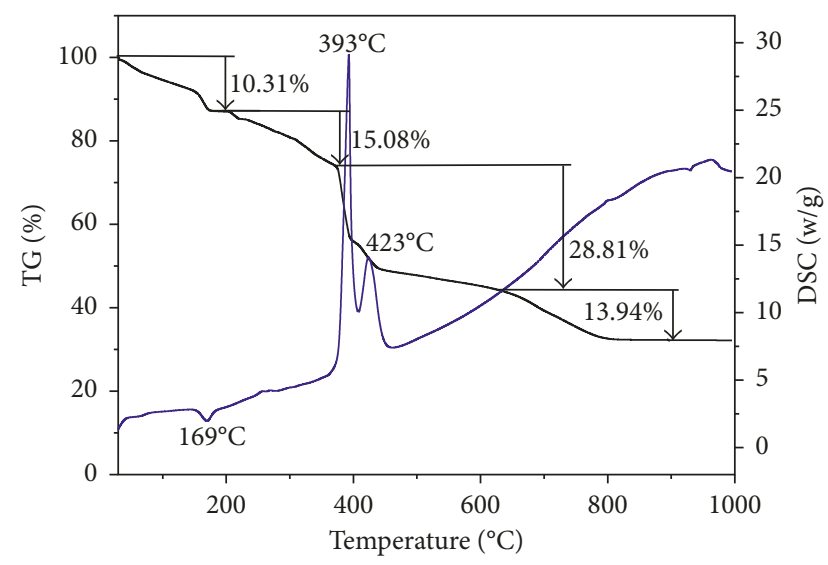

FIGURE 5: TG-DSC curves of the title complex.

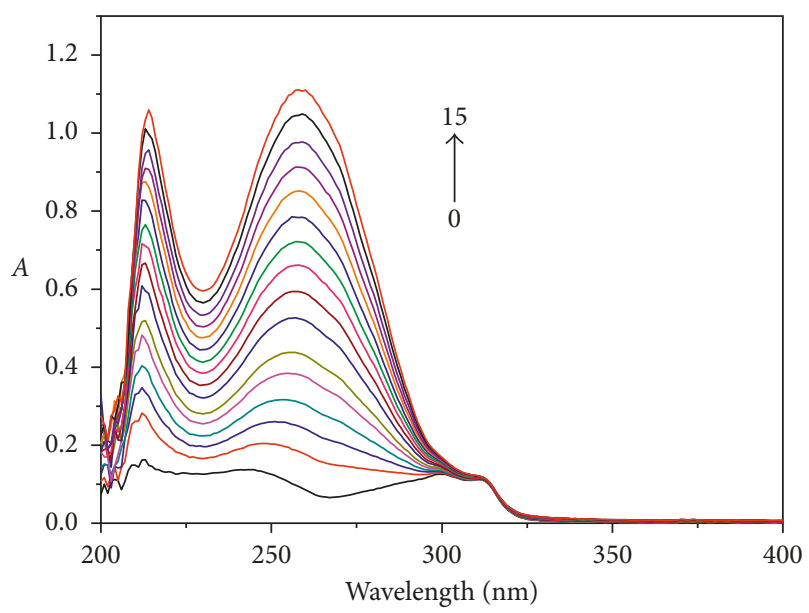

FIgURE 6: Influence of hsDNA on the UV-Vis spectra of Cu-bipy $(\mathrm{pH} 7.40)$. From curves $0-15, c(\mathrm{Cu}-\mathrm{bipy})=4.0 \times 10^{-6} \mathrm{~mol} \cdot \mathrm{L}^{-1}$; $c($ hsDNA $)=0.00,0.17,0.33,0.50,0.67,0.83,1.00,1.17,1.33,1.50$, $1.67,1.83,2.00,2.17,2.33$, and $2.50 \times 10^{-6} \mathrm{~mol} \cdot \mathrm{L}^{-1}$, respectively.

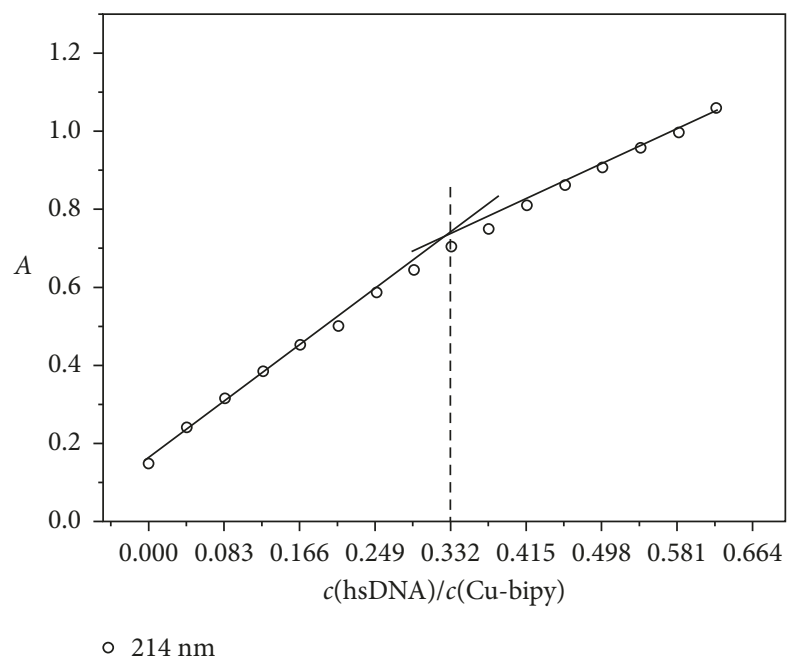

Figure 7: Mole ratio plots of Cu-bipy with hsDNA ( $\mathrm{pH}=7.40$, $\lambda=214 \mathrm{~nm}), c($ Cu-bipy $)=4.0 \times 10^{-6} \mathrm{~mol} \cdot \mathrm{L}^{-1}$.

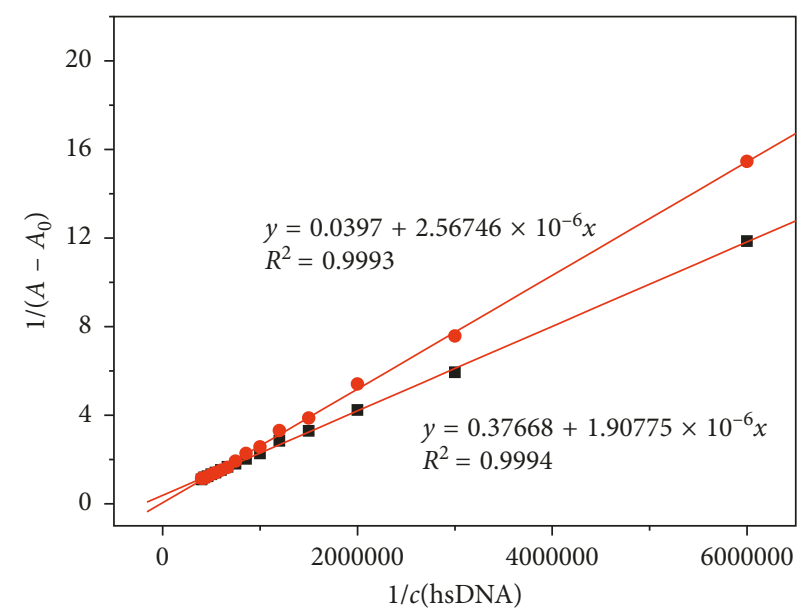

- $295.15 \mathrm{~K}$

- $313.15 \mathrm{~K}$

FIgURE 8: Double reciprocal plots of hsDNA-Cu-bipy at $295.15 \mathrm{~K}$ and $313.15 \mathrm{~K}(\mathrm{pH} 7.40) . c(\mathrm{Cu}$-bipy $)=4.0 \times 10^{-6} \mathrm{~mol} \cdot \mathrm{L}^{-1}$; $c$ (hsDNA $)=0.00,0.60,1.20,1.80,2.40,3.00,3.60,4.20,4.80,5.40$, $6.00,6.60,7.20,7.80$, and $8.40 \times 10^{-6} \mathrm{~mol} \cdot \mathrm{L}^{-1}$, respectively.

TABle 4: Thermodynamic parameters at two different temperatures.

\begin{tabular}{ccccc}
\hline$T(\mathrm{~K})$ & $\begin{array}{c}K^{\ominus} \\
\left(\mathrm{L} \cdot \mathrm{mol}^{-1}\right)\end{array}$ & $\begin{array}{c}\Delta_{\mathrm{r}} G_{\mathrm{m}}^{\ominus} \\
\left(\mathrm{J} \cdot \mathrm{mol}^{-1}\right)\end{array}$ & $\begin{array}{c}\Delta_{\mathrm{r}} S_{\mathrm{m}}^{\ominus} \\
\left(\mathrm{J} \cdot \mathrm{mol}^{-1} \cdot \mathrm{K}^{-1}\right)\end{array}$ & $\begin{array}{c}\Delta_{\mathrm{r}} H_{\mathrm{m}}^{\ominus} \\
\left(\mathrm{J} \cdot \mathrm{mol}^{-1}\right)\end{array}$ \\
\hline 295.15 & $1.97 \times 10^{5}$ & $-3.53 \times 10^{4}$ & 115.26 & -1280 \\
313.15 & $1.55 \times 10^{4}$ & $-2.96 \times 10^{4}$ & 90.44 & -1280 \\
\hline
\end{tabular}

the DSC curve correspond to the oxidation and decomposition of bipy, the decomposition product of this step is $\mathrm{CuSO}_{4}$, and the mass loss of $43.89 \%$ is in agreement with the calculated result of $44.39 \%$. The mass loss remains constant until ca. $800^{\circ} \mathrm{C}$, the final remnant mass is $31.86 \%$, and the residue is $\mathrm{Cu}_{2} \mathrm{SO}_{4}$ (calculated as $31.72 \%$ ).

\subsection{Biological Activity}

3.4.1. Binding Ratio. As shown in Figure 6, the UV-Vis spectra were obtained by determination of the Cu-bipy solution with an independent variable of hsDNA concentration. The wavelength which is obtained from Figure 6 and used in the mole ratio method is $214 \mathrm{~nm}$, and the binding ratio $[n(\mathrm{Cu}$-bipy) $: n($ hsDNA $)=3: 1]$ is shown in Figure 7 .

3.4.2. Double Reciprocal Method. The double reciprocal equation [50] is listed as follows to express the relationship between Cu-bipy and hsDNA:

$$
\left(A-A_{0}\right)^{-1}=A_{0}^{-1}+\left[K^{\ominus} \cdot A_{0} \cdot c(\text { hsDNA })\right]^{-1} .
$$

In (1), $c$ (hsDNA) is the hsDNA concentration, $A$ and $A_{0}$ are the absorbance of $\mathrm{Cu}$-bipy in the presence and lack of hsDNA, respectively, and $K^{\ominus}$ is the binding constant of hsDNA-Cu-bipy. In Figure $8,1 / c$ (hsDNA) is used as an abscissa and $1 /\left(A-A_{0}\right)$ is used as an ordinate. The binding constants are, respectively, calculated: $K^{\ominus}$ 


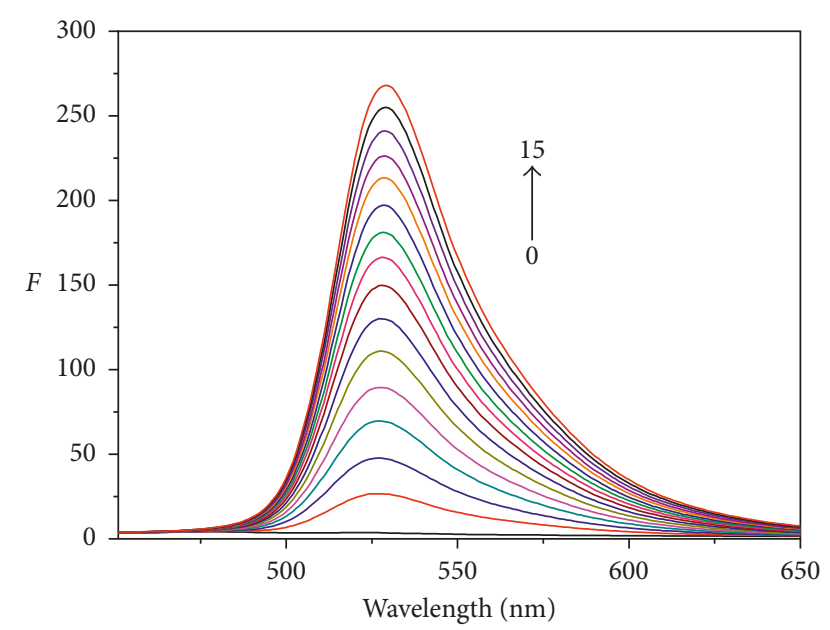

FIGURE 9: Emission spectra of hsDNA-Cu-bipy mixture in different concentrations of $\mathrm{AO}\left(\mathrm{pH}=7.40, \lambda_{\mathrm{ex}}=411.7 \mathrm{~nm}\right)$. From curves $0-15, \quad c($ hsDNA-Cu-bipy $)=1.0 \times 10^{-5} \mathrm{~mol} \cdot \mathrm{L}^{-1} ; \quad c($ Cu-bipy $)=0.00$, $0.33,0.67,1.00,1.33,1.67,2.00,2.33,2.67,3.00,3.33,3.67,4.00$, $4.33,4.67$, and $5.00 \times 10^{-6} \mathrm{~mol} \cdot \mathrm{L}^{-1}$, respectively.

$(295.15 \mathrm{~K})=1.97 \times 10^{5} \mathrm{~L} \cdot \mathrm{mol}^{-1}$ and $K^{\odot}(313.15 \mathrm{~K})=1.55 \times$ $10^{4} \mathrm{~L} \cdot \mathrm{mol}^{-1}$. As is known to all, there are some ways in which macromolecule bind to small molecule, including hydrogen bond, van der Waals force, hydrophobic force, electrostatic interaction, and so on. According to the following equations, we can calculate a series of thermodynamic parameters $\left(\Delta_{\mathrm{r}} H_{\mathrm{m}}^{\ominus}, \Delta_{\mathrm{r}} S_{\mathrm{m}}^{\ominus}\right.$, and $\left.\Delta_{\mathrm{r}} G_{\mathrm{m}}^{\ominus}\right)$ to confirm the interaction forces.

$$
\begin{aligned}
& \ln \frac{K_{2}^{\ominus}}{K_{1}^{\ominus}}=\frac{\Delta_{\mathrm{r}} H_{\mathrm{m}}^{\ominus}\left(\left(1 / T_{1}\right)-\left(1 / T_{2}\right)\right)}{R}, \\
& \Delta_{\mathrm{r}} G_{\mathrm{m}}^{\ominus}=-R T \ln K^{\ominus} \\
& \Delta_{\mathrm{r}} G_{\mathrm{m}}^{\ominus}=\Delta_{\mathrm{r}} H_{\mathrm{m}}^{\ominus}-T \Delta_{\mathrm{r}} S_{\mathrm{m}}^{\ominus},
\end{aligned}
$$

where $T_{1}$ is $295.15 \mathrm{~K}, T_{2}$ is $313.15 \mathrm{~K}$, and $\Delta_{\mathrm{r}} H_{\mathrm{m}}^{\odot}$ and $\Delta_{\mathrm{r}} G_{\mathrm{m}}^{\ominus}$ are the standard molar reaction enthalpy and the standard molar reaction Gibbs free energy, respectively. The calculated results in Table 4 indicate that the interaction between $\mathrm{Cu}$-bipy and hsDNA is driven by entropy [51]. The values of $\Delta_{\mathrm{r}} H_{\mathrm{m}}^{\ominus}$ and $\Delta_{\mathrm{r}} G_{\mathrm{m}}^{\ominus}$ indicate that this is an exothermic reaction, and there is a spontaneous interaction between $\mathrm{Cu}$-bipy and hsDNA.

3.4.3. Competitive Binding Experiments. AO as a fluorescence probe was widely used to study the binding way between small molecule and DNA [38], and it can embed between two adjacent base pairs of DNA helix and enhance the fluorescence intensity. As the concentration of $\mathrm{AO}(\mathrm{Cu}-$ bipy) increases, the fluorescence intensity of $\mathrm{Cu}$-bipyhsDNA (hsDNA-AO) reduces gradually at the maximum wavelength of 528 (531) nm in Figures 9 and 10. The experimental result indicates that the reaction competition between Cu-bipy and AO with hsDNA is conspicuous, and the bonding mode between Cu-bipy and hsDNA mainly includes insertion binding.

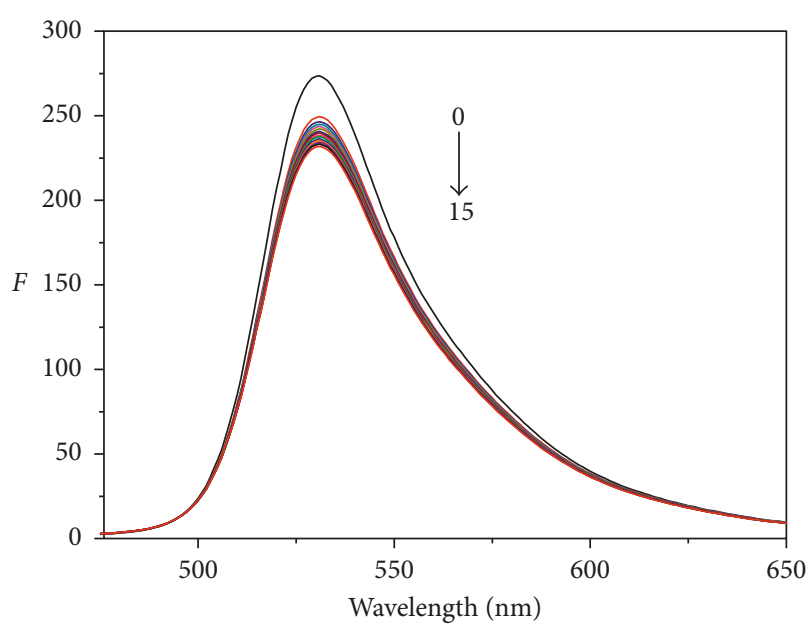

FIgURE 10: Emission spectra of hsDNA-AO mixture in different concentrations of Cu-bipy $\left(\mathrm{pH}=7.40, \lambda_{\mathrm{ex}}=411.7 \mathrm{~nm}\right)$. From curves $0-15, c($ hsDNA-AO $)=1.0 \times 10^{-5} \mathrm{~mol} \cdot \mathrm{L}^{-1} ; c($ Cu-bipy $)=0.00,0.33$, $0.67,1.00,1.33,1.67,2.00,2.33,2.67,3.00,3.33,3.67,4.00,4.33$, 4.67 , and $5.00 \times 10^{-6} \mathrm{~mol} \cdot \mathrm{L}^{-1}$, respectively.

3.4.4. Scatchard Method. The Scatchard equation (3) can be used to study the binding mode between hsDNA and AO with $\mathrm{Cu}$-bipy, whose concentration is gradually changing.

$$
\frac{r}{c}=K(n-r)
$$

where $r$ is the mole number of AO bound per mole of DNA, $c$ is the AO concentration, $K$ is the binding constant, and $n$ is the maximum value of a binding site with AO. Generally, if the $n$ value in the absence of Cu-bipy is the same with the presence of $\mathrm{Cu}$-bipy, the binding mode is an insertion mode. If the $K$ value in the absence of $\mathrm{Cu}$-bipy is the same with the presence of $\mathrm{Cu}$-bipy, there is noninsertion in the binding mode. If the $K$ value is different from the $n$ value, the binding mode between Cu-bipy and hsDNA is a mixed mode of noninsertion and insertion binding. The Scatchard plots in the absence and the presence of sodium chloride are shown in Figures 11 and 12, and the data of $n$ and $K$ are listed in Table 5. It can be seen from Table 5 that both values of $n$ and $K$ vary with the concentrations of $\mathrm{Cu}$-bipy. The results show the presence of the mixed interaction. The $n$ values in the presence of sodium chloride are lower than that of no sodium chloride, and this indicates that there is an electrostatic interaction between Cu-bipy and hsDNA.

3.4.5. Influence of Phosphate Group. The above conclusion is further demonstrated by the phosphate experiment. If $\mathrm{Cu}-$ bipy binds to phosphate radical, then there is an electrostatic interaction between Cu-bipy and hsDNA by changing the $\mathrm{Na}_{2} \mathrm{HPO}_{4}$ concentration while keeping the Cu-bipy concentration fixed. As shown in Figure 13, when the amounts of $\mathrm{Na}_{2} \mathrm{HPO}_{4}$ are increased, UV-Vis spectra of Cu-bipy are slightly changed. The result hints that the electrostatic interaction exists between Cu-bipy and hsDNA. 
Table 5: Data from the Scatchard equation of the interaction between Cu-bipy and hsDNA.

\begin{tabular}{|c|c|c|c|c|c|}
\hline Curve & $c(\mathrm{Cu}-$ bipy $) / c(\mathrm{hsDNA})$ & $\mathrm{NaCl}\left(\mathrm{mol} \cdot \mathrm{L}^{-1}\right)$ & Scatchard & $K\left(\mathrm{~L} \cdot \mathrm{mol}^{-1}\right)$ & $n$ \\
\hline \multirow[b]{2}{*}{ a } & \multirow{2}{*}{0.00} & 0 & $1173.6-2.44 \times 10^{5} r$ & $2.44 \times 10^{5}$ & $4.81 \times 10^{-3}$ \\
\hline & & 0.50 & $813.4-2.09 \times 10^{5} r$ & $2.09 \times 10^{5}$ & $3.89 \times 10^{-3}$ \\
\hline \multirow{2}{*}{$b$} & \multirow{2}{*}{0.40} & 0 & $1176.5-1.81 \times 10^{5} r$ & $1.81 \times 10^{5}$ & $6.50 \times 10^{-3}$ \\
\hline & & 0.50 & $1241.5-2.20 \times 10^{5} r$ & $2.20 \times 10^{5}$ & $5.64 \times 10^{-3}$ \\
\hline \multirow[b]{2}{*}{ c } & \multirow{2}{*}{0.80} & 0 & $1441.2-2.25 \times 10^{5} r$ & $2.25 \times 10^{5}$ & $6.41 \times 10^{-3}$ \\
\hline & & 0.50 & $1318.6-2.21 \times 10^{5} r$ & $2.21 \times 10^{5}$ & $5.97 \times 10^{-3}$ \\
\hline \multirow{2}{*}{ d } & \multirow{2}{*}{1.20} & 0 & $1641.4-2.27 \times 10^{5} r$ & $2.27 \times 10^{5}$ & $7.23 \times 10^{-3}$ \\
\hline & & 0.50 & $1113.9-2.56 \times 10^{5} r$ & $2.56 \times 10^{5}$ & $4.35 \times 10^{-3}$ \\
\hline
\end{tabular}

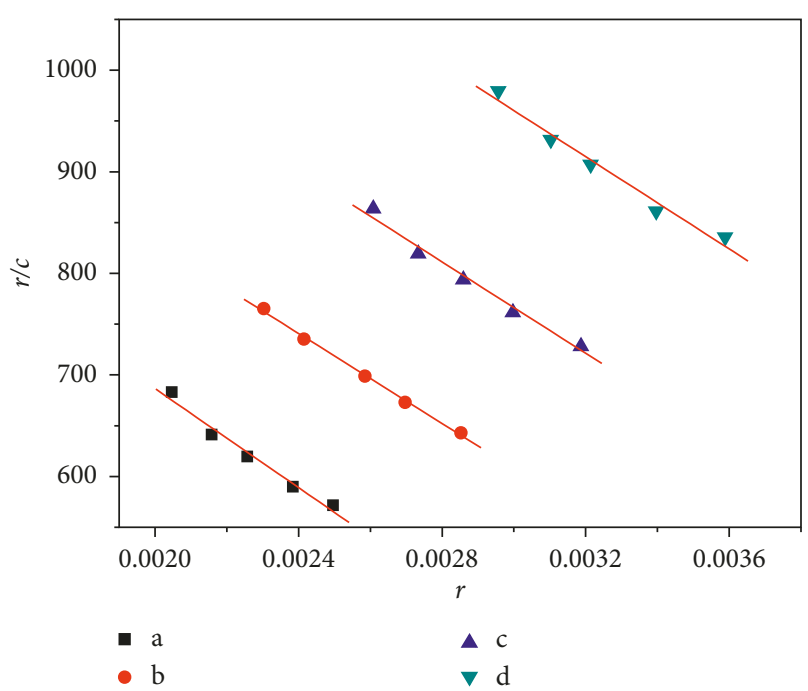

FIGURE 11: Scatchard plots of the interaction between Cu-bipy and hsDNA-AO $(\mathrm{pH}=7.40$, without $\mathrm{NaCl}) . \quad c(\mathrm{hsDNA})=$ $1.0 \times 10^{-5} \mathrm{~mol} \cdot \mathrm{L}^{-1} ; \mathrm{Rt}=c($ Cu-bipy $) / c($ hsDNA $) ; \mathrm{Rt}=\mathrm{a}, 0.00 ; \mathrm{b}, 0.40$; c, $0.80 ; \mathrm{d}, 1.20$.

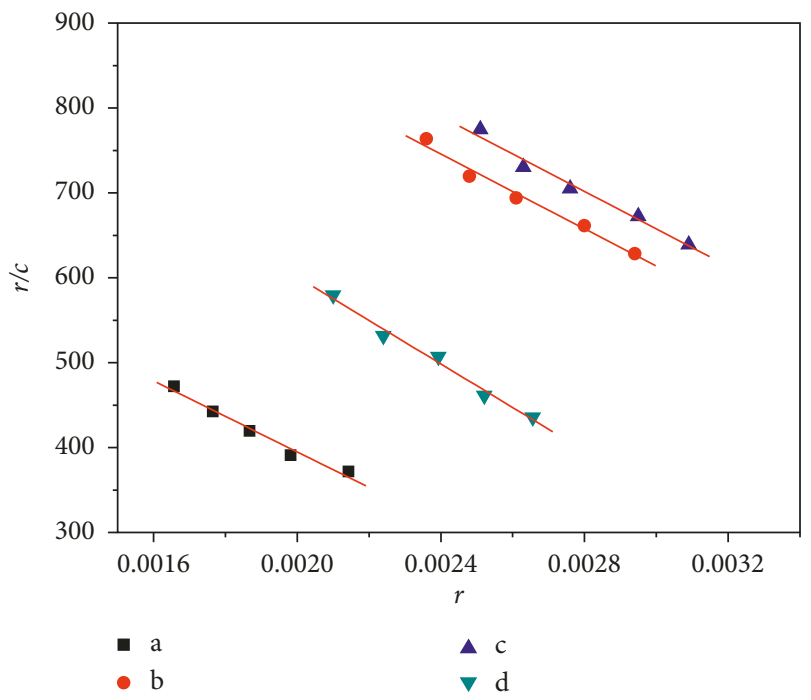

Figure 12: Scatchard plots of the interaction between Cu-bipy and hsDNA-AO $(\mathrm{pH}=7.40, \quad$ with $\mathrm{NaCl}) . \quad c($ hsDNA $)=$ $1.0 \times 10^{-5} \mathrm{~mol} \cdot \mathrm{L}^{-1} ; \mathrm{Rt}=c($ Cu-bipy $) / c($ hsDNA $) ; \mathrm{Rt}=\mathrm{a}, 0.00 ; \mathrm{b}, 0.40$; c, $0.80 ; \mathrm{d}, 1.20$.

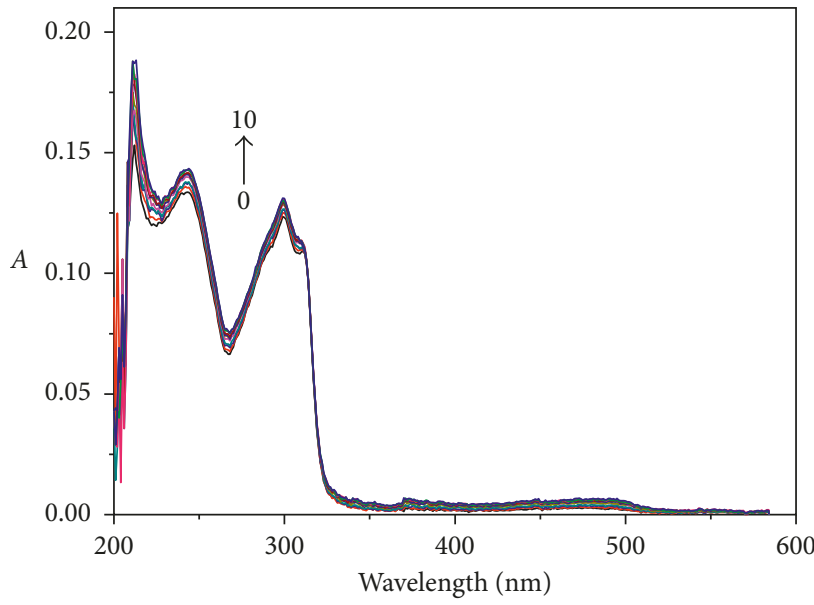

FIGURE 13: Influence of phosphate on the UV-Vis spectra of $\mathrm{Cu}$ bipy $(\mathrm{pH} 7.40) . \quad c(\mathrm{Cu}$-bipy $)=1.0 \times 10^{-5} \mathrm{~mol} \cdot \mathrm{L}^{-1} ; c\left(\mathrm{Na}_{2} \mathrm{HPO}_{4}\right)=$ $0.00,0.33,0.67,1.00,1.33,1.67,2.00,2.33,2.67,3.00,3.33,3.67$, $4.00,4.33,4.67$, and $5.00 \times 10^{-5} \mathrm{~mol} \cdot \mathrm{L}^{-1}$, respectively.

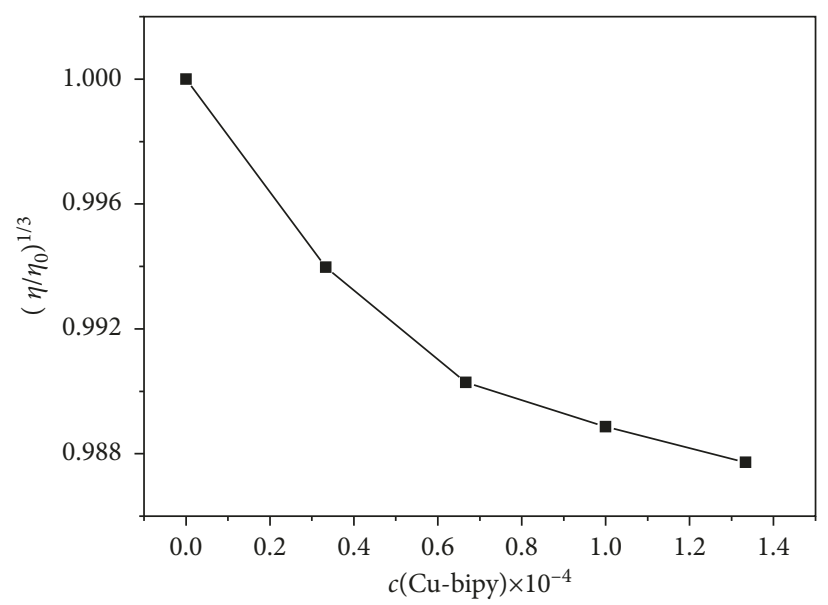

FIGURE 14: Effect of increasing amounts of Cu-bipy on the relative viscosity of hsDNA, $c($ hsDNA $)=1.00 \times 10^{-4} \mathrm{~mol} \cdot \mathrm{L}^{-1}$.

3.4.6. Viscosity Measurements. The viscosity measurements of complexes at different concentrations can obtain useful data for identifying binding mode [41, 52]. If a micromolecule is inserted in the interspace of base pairs, the DNA helix will be extended because the separated base pairs can accommodate the bound ligand. Conversely, the viscosity will not increase if the binding with DNA is in other ways; 
the groove binding does not obviously change viscosity, whereas a partial intercalation of the complex causes a bend in the DNA helix, reducing its viscosity $[53,54]$. The viscosity was determined by the fixed hsDNA concentration and changing the $\mathrm{Cu}$-bipy concentration in the experiment. In Figure 14, the relative viscosity of hsDNA reveals a consistent decrease during the addition of Cu-bipy, which may be due to partial inserting of the complex. According to the result of viscosity measurement, the interaction between Cu-bipy and hsDNA is in insertion mode.

\section{Conclusions}

The complex $\left[\mathrm{Cu} \text { (bipy) }\left(\mathrm{H}_{2} \mathrm{O}\right)_{2}\left(\mathrm{SO}_{4}\right)\right]_{n}$ was synthesized by hydrothermal method and characterized by EA, single crystal X-ray diffraction, FTIR, and TG-DSC. The complex crystallizes in the monoclinic system with $C 2 / c$ space group. The $\mathrm{Cu}(\mathrm{II})$ was hexacoordinated by two $\mathrm{N}$ atoms and four $\mathrm{O}$ atoms, forming a slightly distorted octahedron, and bridged by sulfato groups into polymeric chains. Under the physiological $\mathrm{pH}$, the interaction between the complex and hsDNA was studied with $\mathrm{AO}$ as a fluorescent probe by spectral method. The interaction mechanism of the complex with hsDNA is electrostatic and intercalative binding. The calculated thermodynamic parameters indicate that the interaction of the complex and hsDNA is driven by entropy. The influence of phosphate radical and Scatchard method reveals that the complex is combined with hsDNA in the electrostatic and intromittent modes.

\section{Data Availability}

Crystallographic data have been deposited with the Cambridge Crystallographic Data Centre, CCDC, 12 Union Road, Cambridge CB2 1EZ, UK. Copies of the data can be obtained free of charge on quoting the depository CCDC1028718 for the title complex (Fax: +44-1223-336-033; E-mail: deposit@ccdc.cam.ac.uk, http://www.ccdc.cam.ac.uk).

\section{Conflicts of Interest}

The authors declare that they have no conflicts of interest.

\section{Acknowledgments}

This work was supported by the Scientific Research Funds of Education Department of Sichuan Province (10ZA016) and the Longshan Academic Talent Research Supporting Program of SWUST (17LZX414).

\section{References}

[1] K. A. Kounavi, A. A. Kitos, E. E. Moushi et al., "Supramolecular features in the engineering of $3 \mathrm{~d}$ metal complexes with phenyl-substituted imidazoles as ligands: the case of copper (II)," CrystEngComm, vol. 17, no. 39, pp. 7510-7521, 2015.

[2] K. Soulis, C. Gourlaouen, C. Daniel et al., "New luminescent copper(I) complexes with extended $\pi$-conjugation," Polyhedron, vol. 140, pp. 42-50, 2018.
[3] P. A. Tanner and C. K. Duan, "Luminescent lanthanide complexes: selection rules and design," Coordination Chemistry Reviews, vol. 254, no. 23-24, pp. 3026-3029, 2010.

[4] S. Sanram, J. Boonmak, and S. Youngme, "Structural diversity, single-crystal to single-crystal transformation and photocatalytic properties of $\mathrm{Cu}(\mathrm{II})$-metal-organic frameworks based on 1,4-phenylenedipropionic acid," Inorganica Chimica Acta, vol. 469, pp. 11-19, 2018.

[5] J. Cui, Y. Li, Z. Guo, and H. Zheng, "A porous metal-organic framework based on $\mathrm{Zn}_{6} \mathrm{O}_{2}$ clusters: chemical stability, gas adsorption properties and solvatochromic behavior," Chemical Communications, vol. 49, no. 6, pp. 555-557, 2013.

[6] R. Yang, H. H. Li, K. V. Hecke, and G. H. Cui, "Cobalt(II) and copper(II) complexes constructed from bis(benzimidazole) and 2,6-pyridinedicarboxylate Co-ligands: synthesis, crystal structures, and catalytic properties," Zeitschrift für Anorganische und Allgemeine Chemie, vol. 641, no. 3-4, pp. 642-649, 2015.

[7] H. Paul, T. Mukherjee, M. G. B. Drew, and P. Chattopadhyay, "Synthesis, characterization, crystal structure, and DNAbinding of ruthenium(II) complexes of heterocyclic nitrogen ligands resulting from a benzimidazole-based quinazoline derivative," Journal of Coordination Chemistry, vol. 65, no. 8, pp. 1289-1302, 2012.

[8] J. Luo, L. Qiu, B. Liu, X. Zhang, F. Yang, and L. Cui, "Synthesis, structure and magnetic properties of two cobalt(II) dicyanamide ( $\mathrm{dca}$ ) complexes with heterocyclic nitrogen donors tetra(2-pyridyl)pyrazine (tppz) and 2,4,6-tri(2-pyridyl)-1,3,5triazine (tptz): $\left[\mathrm{Co}_{2}(\mathrm{tppz})(\mathrm{dca})_{4}\right] \cdot \mathrm{CH}_{3} \mathrm{CN}$ and $[\mathrm{Co}(\mathrm{tptz})(\mathrm{dca})$ $\left.\left(\mathrm{H}_{2} \mathrm{O}\right)\right](\mathrm{dca}), "$ Chinese Journal of Chemistry, vol. 30, no. 3, pp. 522-528, 2012.

[9] W. Levason, G. Reid, and W. Zhang, "Synthesis, properties, and structures of chromium(VI) and chromium(V) complexes with heterocyclic nitrogen Ligands," Zeitschrift Für Anorganische und Allgemeine Chemie, vol. 640, no. 1, pp. 35-39, 2014.

[10] J. Devi and N. Batra, "Synthesis, characterization and antimicrobial activities of mixed ligand transition metal complexes with isatin monohydrazone Schiff base ligands and heterocyclic nitrogen base," Spectrochimica Acta Part A: Molecular and Biomolecular Spectroscopy, vol. 135, pp. 710719, 2014.

[11] H. Wu, F. Kou, F. Jia, B. Liu, J. Yuan, and Y. Bai, "Synthesis, characterization, DNA-binding properties, and antioxidant activity of a copper(II) complex with 1,3-bis-(1-allaylbenzimidazol2-yl)-2-oxopropane," Zeitschrift für Anorganische und Allgemeine Chemie, vol. 638, no. 2, pp. 443-450, 2012.

[12] X. Qiao, Z.-Y. Ma, C.-Z. Xie et al., "Study on potential antitumor mechanism of a novel Schiff base copper(II) complex: synthesis, crystal structure, DNA binding, cytotoxicity and apoptosis induction activity," Journal of Inorganic Biochemistry, vol. 105, no. 5, pp. 728-737, 2011.

[13] Y.-M. Ji, Y. Fang, P.-P. Han, M.-X. Li, Q.-Q. Chen, and Q.-X. Han, "Copper(II) and cadmium(II) complexes derived from Strandberg-type polyoxometalate clusters: synthesis, crystal structures, spectroscopy and biological activities," Inorganic Chemistry Communications, vol. 86, pp. 22-25, 2017.

[14] M. Jiang, Y.-T. Li, Z.-Y. Wu, Z.-Q. Liu, and C.-W. Yan, "Synthesis, crystal structure, cytotoxic activities and DNAbinding properties of new binuclear copper(II) complexes bridged by $N, N^{\prime}$-bis( $N$-hydroxyethylaminoethyl)oxamide," Journal of Inorganic Biochemistry, vol. 103, no. 5, pp. 833-844, 2009. 
[15] Y. Huang, E. Kong, J. Zhan et al., "Synthesis and cytotoxic evaluation of steroidal copper (Cu(II)) complexes," Bioinorganic Chemistry and Applications, vol. 2017, Article ID 4276919, 6 pages, 2017.

[16] J. D. C. Almeida, D. A. Paixão, I. M. Marzano et al., "Copper (II) complexes with $\beta$-diketones and $\mathrm{N}$-donor heterocyclic ligands: crystal structure, spectral properties, and cytotoxic activity," Polyhedron, vol. 89, pp. 1-8, 2015.

[17] M. Nasrollahzadeh, A. Zahraei, A. Ehsani, and M. Khalajc, "Synthesis, characterization, antibacterial and catalytic activity of a nanopolymer supported copper(II) complex as a highly active and recyclable catalyst for the formamidation of arylboronic acids under aerobic conditions," RSC Advances, vol. 4, no. 39, pp. 20351-20357, 2014.

[18] A. D. Naik, P. A. N. Reddy, M. Nethaji, and A. R. Chakravarty, "Ternary copper(II) complexes of thiosemicarbazones and heterocyclic bases showing $\mathrm{N}_{3} \mathrm{OS}$ coordination as models for the type-2 centers of copper monooxygenases," Inorganica Chimica Acta, vol. 349, no. 3, pp. 149-158, 2003.

[19] K. Ghosh, P. Kumar, N. Tyagi et al., "DNA interaction, superoxide scavenging and cytotoxicity studies on new copper (II) complexes derived from a tridentate ligand," Polyhedron, vol. 30, no. 16, pp. 2667-2677, 2011.

[20] Z. Chen, J. Zhang, P. Zeng, S. Zhang, and C. Jin, "Evaluation of DNA binding, protein interaction, and cytotoxic activity of a mononuclear copper(II) complex," Zeitschrift für Anorganische und Allgemeine Chemie, vol. 640, no. 7, pp. 1506-1513, 2014.

[21] D. Dey, A. De, S. Pal et al., "Synthesis, crystal structure, catecholase activity, DNA cleavage and anticancer activity of a dinuclear manganese(III)-bipyridine complex," Indian Journal of Chemistry, vol. 54A, no. 2, pp. 170-178, 2015.

[22] T. S. Lobana, S. Indoria, A. K. Jassal, H. Kaur, D. S. Arora, and J. P. Jasinski, "Synthesis, structures, spectroscopy and antimicrobial properties of complexes of copper(II) with salicylaldehyde $N$-substituted thiosemicarbazones and 2,2'bipyridine or 1,10-phenanthroline," European Journal of Medicinal Chemistry, vol. 76, pp. 145-154, 2014.

[23] Y.-Q. Zheng and J.-L. Lin, "Crystal structures of $\left[\mathrm{Cu}_{2}(\mathrm{bpy})_{2}\left(\mathrm{H}_{2} \mathrm{O}\right)\right.$ $\left.(\mathrm{OH})_{2}\left(\mathrm{SO}_{4}\right)\right] \cdot 4 \mathrm{H}_{2} \mathrm{O}$ and $\left[\mathrm{Cu}(\mathrm{bpy})\left(\mathrm{H}_{2} \mathrm{O}\right)_{2}\right] \mathrm{SO}_{4}$ with bpy $=2,2^{\prime}$ bipyridine," Zeitschrift für Anorganische und Allgemeine Chemie, vol. 629, no. 9, pp. 1622-1626, 2003.

[24] S. Sanotra, R. Gupta, H. N. Sheikh, B. L. Kalsotra, V. K. Gupta, and Rajnikant, "Hydrothermal synthesis and crystal structure of a supramolecular dinuclear cobalt(II) complex containing the dianion of pyridine-2,6-dicarboxylic acid," Monatshefte fur Chemie, vol. 144, no. 12, pp. 18071813, 2013.

[25] Y. V. Kolen'ko, V. D. Maximov, A. V. Garshev, P. E. Meskin, N. N. Oleynikov, and B. R. Churagulov, "Hydrothermal synthesis of nanocrystalline and mesoporous titania from aqueous complex titanyl oxalate acid solutions," Chemical Physics Letters, vol. 388, no. 4-6, pp. 411-415, 2004.

[26] M.-S. Chen, Y.-F. Deng, X. Nie, and C.-H. Zhang, "Hydrothermal synthesis, crystal structure, and luminescence property of an $\mathrm{Mn}$ - $\mathrm{Tb}$ complex based on 5-(isonicotinamido)isophthalate," Synthesis and Reactivity in Inorganic, MetalOrganic, and Nano-Metal Chemistry, vol. 44, no. 6, pp. 868-872, 2014.

[27] Y.-F. Wang, Z. Li, Y.-C. Sun, and J.-S. Zhao, "Hydrothermal synthesis, crystal structures, and characterization of two copper complexes with 3-amino-1,2,4-triazole," Synthesis and Reactivity in Inorganic, Metal-Organic, and Nano-Metal Chemistry, vol. 44, no. 2, pp. 277-281, 2014.
[28] P. Zhao, W. Jing, L. Jing, F. Jian, and Y. Li, "Hydrothermal synthesis, crystal structures and properties of zinc(II) dinuclear complex and copper(I) coordination polymer based on building block 2-phenyl-4,6-di(pyridine-2-yl)pyrimidine," Bulletin of the Korean Chemical Society, vol. 34, no. 12, pp. 3743-3748, 2013.

[29] H. A. J. L. Mourão, O. F. Lopes, A. R. Malagutti, E. C. Paris, and C. Ribeiro, "Hydrothermal synthesis and photocatalytic properties of anatase $\mathrm{TiO}_{2}$ nanocrystals obtained from peroxytitanium complex precursor," Materials Science in Semiconductor Processing, vol. 25, pp. 320-329, 2014.

[30] Y.-H. Wen, J.-K. Cheng, Y.-L. Feng, J. Zhang, Z.-J. Li, and Y.-G. Yao, "Hydrothermal syntheses, crystal structures and characterizations of three new copper coordination polymers," Inorganica Chimica Acta, vol. 358, no. 12, pp. 33473354, 2005.

[31] X. Li, C.-F. Bi, Y.-H. Fan, X. Zhang, N. Zhang, and X.-C. Yan, "Synthesis, crystal structure and DNA interaction of a novel three-nuclear cobalt(II) complex with Schiff base derived from 4-chloroanthranilic acid and 2,4-dihydroxybenzaldehyde," Journal of Inorganic and Organometallic Polymers and Materials, vol. 24, no. 3, pp. 582-590, 2014.

[32] M. Hazra, T. Dolai, A. Pandey, S. K. Dey, and A. Patra, "Synthesis and characterisation of copper(II) complexes with tridentate NNO functionalized ligand: density function theory study, DNA binding mechanism, optical properties, and biological application," Bioinorganic Chemistry and Applications, vol. 2014, Article ID 104046, 13 pages, 2014.

[33] P. Haribabu, R. K. Hussain, Y. P. Patil, and M. Nethaji, "Synthesis, crystal structure, DNA binding and cleavage activities of oximato bridged cationic dinuclear copper(II) complex having labile ligands," Indian Journal of Chemistry, vol. 52A, no. 3, pp. 327-333, 2013.

[34] M. Pragathi and K. H. Reddy, "Synthesis, spectral characterization and DNA interactions of copper(II) and nickel(II) complexes with unsymmetrical Schiff base ligands," Indian Journal of Chemistry, vol. 52A, no. 7, pp. 845-853, 2013.

[35] X.-G. Shu, C.-L. Wu, C.-J. Li, M. Zhang, K. Wan, and X. Wu, "Synthesis, crystal structure, spectroscopic properties, and interaction with Ct-DNA of $\mathrm{Zn}$ (II) with 2-aminoethanethiol hydrochloride ligand," Bioinorganic Chemistry and Applications, vol. 2016, Article ID 2691253, 7 pages, 2016.

[36] Z.-Q. Liu, Y.-T. Li, Z.-Y. Wu, and S.-F. Zhang, " $\left[\mathrm{Cu}_{4}\left(\mathrm{H}_{2} \mathrm{O}\right)_{4}\right.$ (dmapox $\left.)_{2}(\mathrm{btc})\right]_{n} \cdot 10 n \mathrm{H}_{2} \mathrm{O}$ : the first two-dimensional polymeric copper(II) complex with bridging $\mu$-trans-oxamidate and $\mu_{4}$-1,2,4,5-benzentetracarboxylato ligands: synthesis, crystal structure and DNA binding studies," Inorganica Chimica Acta, vol. 362, no. 1, pp. 71-77, 2009.

[37] R. S. Kumar and S. Arunachalam, "DNA binding and antimicrobial studies of polymer-copper(II) complexes containing 1,10-phenanthroline and 1-phenylalanine ligands," European Journal of Medicinal Chemistry, vol. 44, no. 5, pp. 1878-1883, 2009.

[38] J. Long, X.-M. Wang, D.-L. Xu, and L.-S. Ding, "Spectroscopic studies on the interaction mechanisms of safranin $\mathrm{T}$ with herring sperm DNA using acridine orange as a fluorescence probe," Journal of Molecular Recognition, vol. 27, no. 3, pp. 131-137, 2014.

[39] G. M. Sheldrick, SHELXS-97, Program for the Solution of Crystal Structure, University of Göttingen, Göttingen, Germany, 1997.

[40] G. M. Sheldrick, SHELXL-97, Program for the Refinement of Crystal Structure, University of Göttingen, Göttingen, Germany, 1997. 
[41] Q. Zang, G.-Q. Zhong, and M.-L. Wang, "A copper(II) complex with pyridine-2,6-dicarboxylic acid: synthesis, characterization, thermal decomposition, bioactivity and interactions with herring sperm DNA," Polyhedron, vol. 100, pp. 223-230, 2015.

[42] W. Kirk-Othmer, Encyclopedia of Chemical Technology, Vol. 9, Wiley, New York, NY, USA, 1998.

[43] D. Li and G.-Q. Zhong, "Synthesis and crystal structure of the bioinorganic complex [Sb(Hedta)] $2 \mathrm{H}_{2} \mathrm{O}$," Bioinorganic Chemistry and Applications, vol. 2014, Article ID 461605, 7 pages, 2014.

[44] E. H. Lizarazo-Jaimes, P. G. Reis, F. M. Bezerra et al., "Complexes of different nitrogen donor heterocyclic ligands with $\mathrm{SbCl}_{3}$ and $\mathrm{PhSbCl}_{2}$ as potential antileishmanial agents against $\mathrm{Sb}^{\mathrm{III}}$-sensitive and -resistant parasites," Journal of Inorganic Biochemistry, vol. 132, pp. 30-36, 2014.

[45] K. Nakamoto, Infrared and Raman Spectra of Inorganic and Coordination Compounds, John Wiley \& Sons Inc., New York, NY, USA, 6th edition, 2009.

[46] J. J. Murcia, M. C. Hidalgo, J. A. Navío, J. Araña, and J. M. Doña-Rodríguez, "In situ FT-IR study of the adsorption and photocatalytic oxidation of ethanol over sulfated and metallized $\mathrm{TiO}_{2}$," Applied Catalysis B: Environmental, vol. 142-143, pp. 205-213, 2014.

[47] G.-Q. Zhong and Q. Zhong, "Solid-solid synthesis, characterization, thermal decomposition and antibacterial activities of zinc(II) and nickel(II) complexes of glycine-vanillin Schiff base ligand," Green Chemistry Letters and Reviews, vol. 7, no. 3, pp. 236-242, 2014.

[48] I. Das, S. A. Ansari, and N. R. Agrawal, "Growth of nanosized cupric sulphate-urea complex in aqueous medium and its characterization," Indian Journal of Chemistry, vol. 50A, no. 6 , pp. 798-801, 2011.

[49] W. Zhong, G.-Q. Zhong, and J.-H. He, "Preparation of tribasic copper chloride nanopowders by solid state reaction at room temperature," Journal of Synthetic Crystals, vol. 39, no. 6, pp. 1581-1585, 2010.

[50] A. Rescifina, M. G. Varrica, C. Carnovale, G. Romeo, and U. Chiacchio, "Novel isoxazole polycyclic aromatic hydrocarbons as DNA-intercalating agents," European Journal of Medicinal Chemistry, vol. 51, pp. 163-173, 2012.

[51] P. D. Ross and S. Subramanian, "Thermodynamics of protein association reactions: forces contributing to stability," Biochemistry, vol. 20, no. 11, pp. 3096-3102, 1981.

[52] S. J. Kharat and P. S. Nikam, "Density and viscosity studies of binary mixtures of aniline + benzene and ternary mixtures of (aniline + benzene $+N, N$-dimethylformamide) at 298.15, 303.15, 308.15, and 313.15 K," Journal of Molecular Liquids, vol. 131-132, pp. 81-86, 2007.

[53] S. Satyanarayana, J. C. Dabrowiak, and J. B. Chaires, "Neither $\Delta$ - nor $\Lambda$-tris(phenanthroline)ruthenium(II) binds to DNA by classical intercalation," Biochemistry, vol. 31, no. 39, pp. 9319-9324, 1992.

[54] Z.-G. Zhang and X.-D. Dong, "Interaction of DNA with a novel photoactive platinum diimine complex," BioMetals, vol. 22, no. 2, pp. 283-288, 2009. 

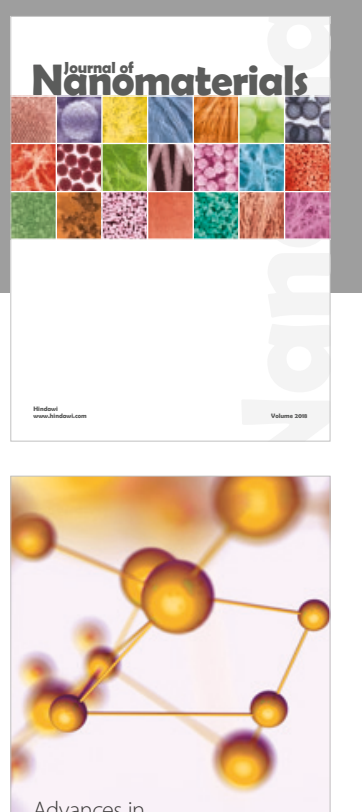

Physical Chemistry
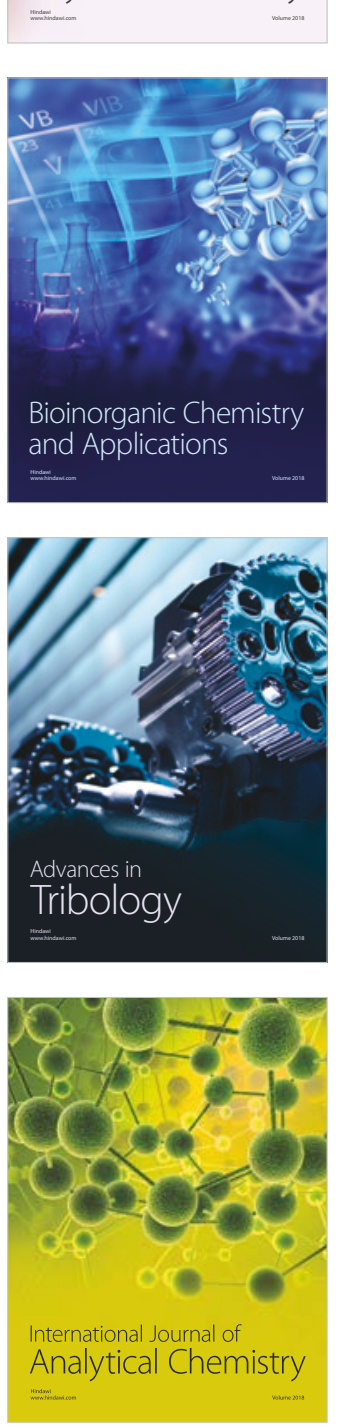

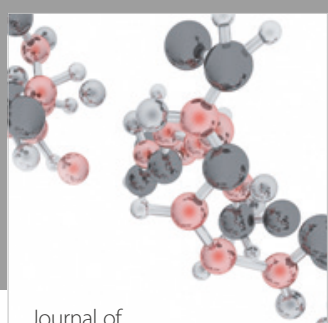

Analytical Methods

in Chemistry

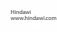

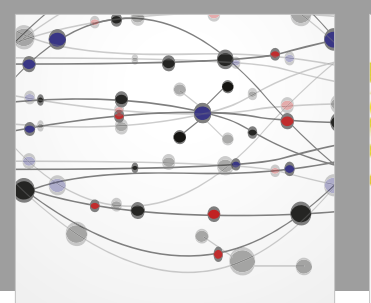

The Scientific World Journal

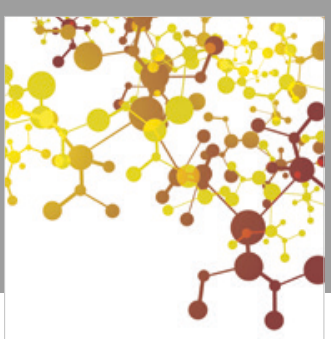

Journal of

Applied Chemistry
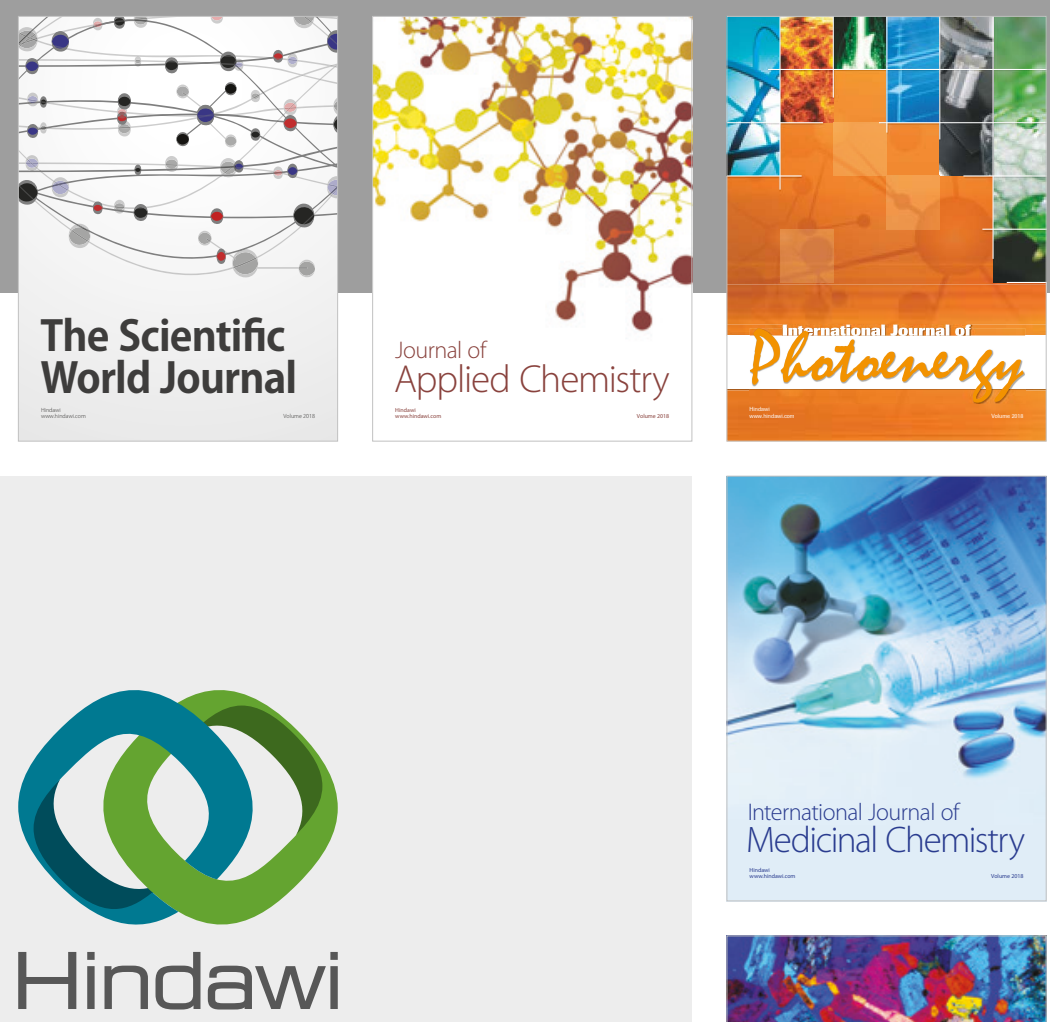

Submit your manuscripts at

www.hindawi.com
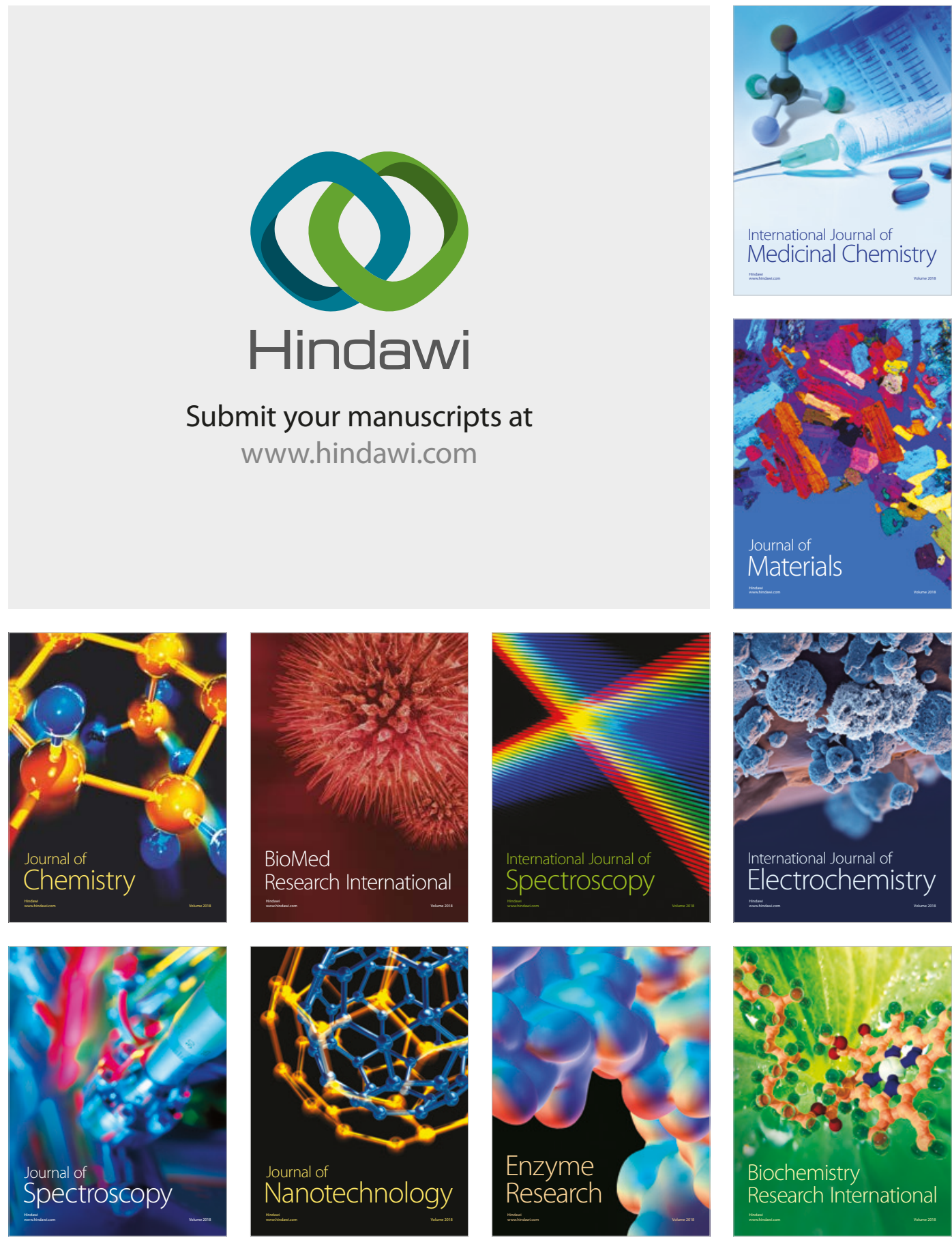
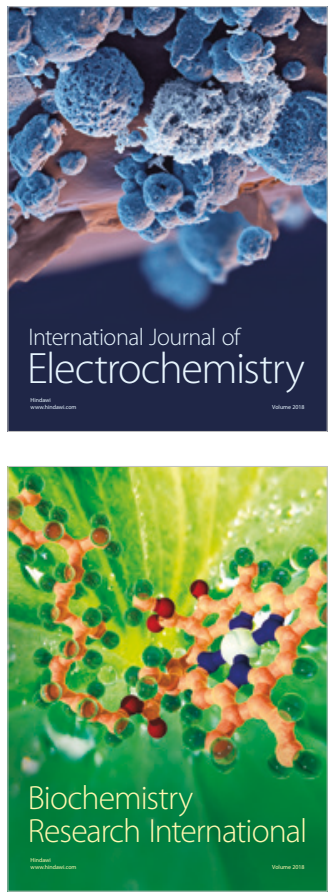